\title{
ЦИФРОВІЗАЦІЯ СУСПІЛЬСТВА ТА ОРГАНІЗАЦІЙНО-ПРАВОВІ МЕХАНІЗМИ ФУНКЦІОНУВАННЯ ЄДИНОГО ДЕРЖАВНОГО РЕЄСТРУ ПРИЗОВНИКІВ, ВІЙСЬКОВОЗОБОВ'ЯЗАНИХ ТА РЕЗЕРВІСТІВ
}

У статті охарактеризовано організаційно-правові механізми функціонування Єдиного державного реєстру призовників, військовозобов'язаних та резервістів. Проведено аналіз нормативноправового забезпечення державних механізмів функціонування Єдиного державного реєстру призовників, військовозобов'язаних та резервістів, як напрям державної політики Украӥни. Обгрунтовано рекомендації щодо удосконалення нормативно-правових актів, які визначають організаційно-правові механізми функціонування Єдиного державного реєстру призовників, військовозобов'язаних та резервістів.

Застосування ичих рекомендацій у практичній діяльності Центральних органів виконавчої влади, зокрема у ході формуванні політики циффрової трансформації у Міністерстві оборони Украйни щьодо інтеграції Сдиного державного реєстру призовників, військовозобов'язаних та резервістів запровадить необхідні правові механізми для організації та забезпечення інформаційної взаємодії між державними реєстрами в інтересах ведення військового обліку громадян України для комплектування військ (сил) особовим складом.

Крім того, практична реалізачія рекомендацій створить правові засади для реалізаціі Міністерством оборони Украӥни проєктів передбачених Планом дій Уряду щуодо запровадження електронних військово-облікових документів та створення електронного Територіального центру комплектування та сочіальної підтримки.

Ключові слова: Сдиний державний реєстр призовників, військовозобов'язаних та резервістів, інтеграція, цฺифровізація.

Вступ

Постановка проблеми. Цифровізація в сучасному світі є глобальним процесом, який викликаний стрімким розвитком інформаційних технологій, мікроелектроніки і комунікацій. При цьому основним напрямом трансформації суспільства виступає цифровізація, яка грунтується на тотальному впровадженні інформаційних технологій та орієнтована на глибоке перетворення продуктів, бізнес- i операційної моделі процесів взаємодії між користувачами і постачальниками послуг. Основні переваги цифровізації пов'язані 3 динамічними підходами використання даних i створенням цифрових платформ, що збільшує достовірність інформації та оперативність в доступі до інформації та її обробці.

У державно-правовому сенсі цифрову трансформацію можна розглядати як політику i процес впливу держави на суспільство загалом, його інституції, апарат самої держави, економіку і бізнес із метою впровадження цифрових інформаційно-комунікаційних технологій в життедіяльність [1].

Сьогодні цифрове перетворення - це бізнесстратегія, в якій технології забезпечують інновації та креативність, на основі чого компанії покращують ефективність свого функціонування.

У свою чергу, впровадження цифрових технологій в процесах управління в державі та життєдіяльності суспільства, відмова від паперових носіїв інформації, їх подальша заміна електронними носіями $\epsilon$ пріоритетними завданнями з реформування держави, у тому числі в галузі оборони, зокрема щодо функціонування системи військового обліку призовників, військовозобов'язаних та резервістів (далі - СВО).

Останні десятиріччя XX та початку XXI століття характеризуються переходом збройних сил передових у військовому відношенні країн світу до автоматизованого управління військами (силами) і зброєю. Армії майже усіх провідних держав мають на озброєнні автоматизовані системи управління військами (силами). Автоматизоване управління військами і зброєю у часі, близькому до реального, та єдине інформаційне середовище прийняття управлінських рішень на застосування військ (сил) та зброї стали вирішальним чинником досягнення успіху в бою (операції) [2].

Результати практичної діяльності 3 комплектування військ (сил) особовим складом в ході проведення мобілізації у 2014-2015 роках викрили низку проблемних питань у 
функціонуванні $\mathrm{CBO}$, що впливають на ефективність процесу комплектування військ (сил) особовим складом, який $\epsilon$ основою бойового потенціалу Збройних Сил України (далі - 3СУ) [3].

Зазначена проблема пов'язана 3 незадовільними показниками оперативності та достовірності відомостей щодо наявних загальних людських ресурсів в державі, зокрема людських мобілізаційних ресурсів.

Основна причина зниження оперативності та достовірності даних військового обліку громадян України персонально-якісними та кількісними показниками, які циркулюють в СВО поряд 3 іншими полягає у відсутності необхідного рівня автоматизації бізнес процесів військового обліку громадян, які здійснюються в її елементах.

Крім того, аналіз результатів практичної роботи з впровадження в діяльність ЗСУ сучасних автоматизованих інформаційнотелекомунікаційних систем (далі - AITC), зокрема Сдиного державного реєстру призовників, військовозобов'язаних та резервістів (далі СДРПВР), в черговий раз підтверджує їх зростаючу залежність від нормативно-правового забезпечення, що визначає організаційно-правові механізми його функціонування [4].

Актуальність бізнес процесів 3 військового обліку полягає у необхідності забезпечення захисту суверенітету і територіальної цілісності, що $є$ найвищою конституційною [5] функцією держави та справою всього українського народу 3 одного боку, та наданні можливості громадянам відповідних сервісів у доступі до інформації, яка знаходиться в інформаційних ресурсах держави для реалізації їх конституційних прав і свобод 3 іншого.

Отже, проблема реалізація завдань 3 автоматизації та цифрової трансформації бізнес процесів з військового обліку громадян України на сучасному етапі полягає у відсутності необхідних правових норм, які б надали можливість якісно виконати оперативні завдання визначені Урядом [6]. При цьому, складність нормативного забезпечення цих процесів полягає у визначенні правових відносин між громадянином та автоматизованою системою, яка виконує функції держави.

Таким чином, нормативно-правова база військового обліку громадян України потребує удосконалення, зокрема у частині, що стосується створення правових засад запровадження автоматизації та цифрової трансформації бізнес процесів 3 військового обліку та функціонування CBO 3 урахуванням інтеграційних процесів СДРПВР з іншими державними реєстрами.

Аналіз остатніх досліджень і публікацій. Результати аналізу останніх досліджень i публікацій присвячених СДРПВР [7]-[10] показав, що проблеми нормативно-правого забезпечення його функціонування досліджувалися та розглядалися але не у повному обсязі.

Метою даної статті $\epsilon$ обгрунтування рекомендації щодо удосконалення нормативноправових актів, які визначають організаційноправові механізми функціонування СДРПВР.

\section{Виклад основного матеріалу}

\section{дослідження}

Проблеми нормативно-правового забезпечення створення автоматизованої системи військового обліку громадян України, зокрема проблем практичної реалізації процесів автоматизації військового обліку та створення Єдиного державного реєстру військовозобов'язаних розпочались розглядатися у 2015 році [2]. У зазначеній роботі було запропоновано структуру i зміст майбутнього Закону України Закон України "Про Єдиний державний реєстр військовозобов'язаних" [11] але прийнятий цей закон був лише 16 березня 2017 року.

На його виконання МОУ було розроблено Порядок ведення ЄДРВ [12], а ГШ ЗСУ низку документів $з$ його організаційно функціонування та захисту інформації.

Відповідно до [13] в МОУ розгорнута та функціонує АІТС ЄДРПВР “Оберіг”.

Зазначена AITC призначена для збирання, зберігання, обробки та використання даних про призовників, військовозобов'язаних та резервістів, створена для забезпечення військового обліку громадян України [14].

Володільцем ЄДРПВР є МОУ, а розпорядниками Генеральний штаб (далі - ГШ) ЗСУ, Служба безпеки України (далі - СБУ) та Служба зовнішньої розвідки України (далі С3РУ).

До основних завдань СДРПВР належить:

ведення військового обліку громадян України;

забезпечення комплектування ЗСУ особовим складом в мирний час та в особливий період;

інформаційне забезпечення громадян України, у тому числі осіб, звільнених з військової служби, які мають право на пенсію, та членів сімей загиблих військовослужбовців відомостями щодо виконання ними військового обов'язку.

До складу ЄДРПВР входять органи адміністрування та ведення.

До органів адміністрування ЄДРПВР належать: уповноважений орган адміністрування володільця ЄДРВПР;

оперативні командування;

територіальні центри комплектування та соціальної підтримки (далі - ТЦК та СП), Автономної Республіки Крим, областей, міст Києва та Севастополя;

Центральне управління СБУ та відповідний підрозділ СЗРУ.

До органів ведення СДРПВР належать районні (об'єднані районні), міські (районні у місті, об’єднані міські) ТЦК та СП, Центральне управління СБУ та регіональні органи СБУ, відповідні підрозділи СЗРУ.

Існуюча архітектура серверних рішень АITC “Оберіг” наведена на рис. 1. 


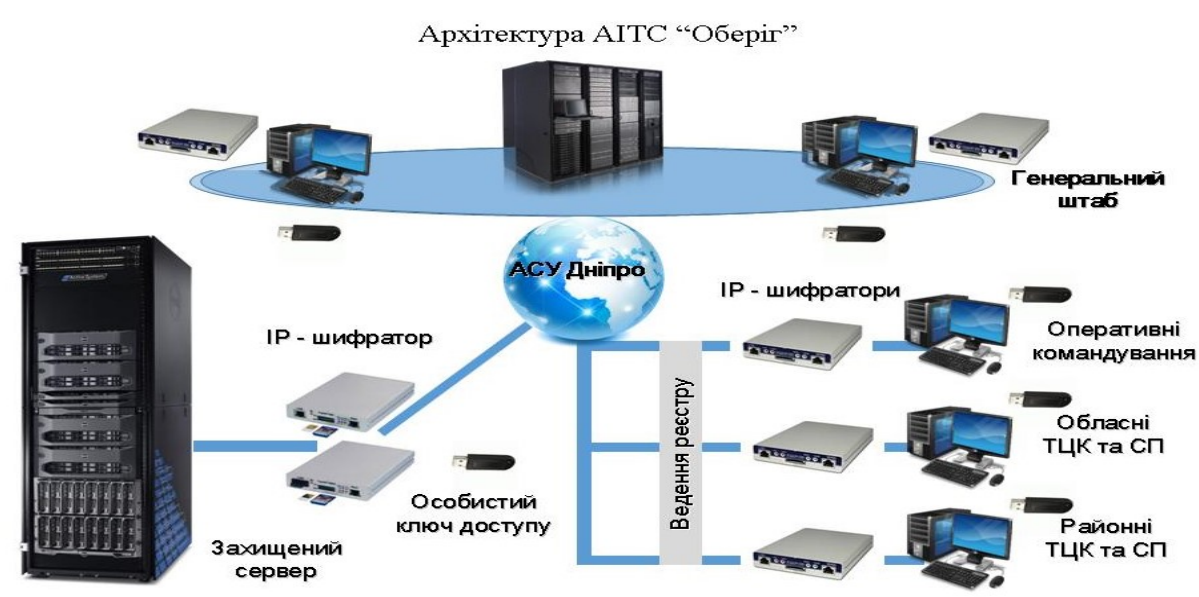

Рис. 1. Існуюча архітектура серверних рішень АITC

Основа створення бази даних ЄДРПВР полягає у застосуванні принципу формування централізованої бази даних на віддаленому доступі, а функціонування її головного елементу в інтересах всієї системи управління в цілому в режимі миттєвого доступу - “тонкій клієнт”.

Автоматизовані робочі місця (далі - АРМ) клієнтської частини (далі - КЧ) в кількості одного АРМ розгорнуті в органах адміністрування та ведення реєстру, без урахування СБУ та СЗРУ.

Центральний сервер розгорнуто в ГШ ЗСУ, а резервний на одному із захищених ПУ.

Для обміну інформацією використовують телекомунікаційну мережу ЗСУ.

Захист інформації здійснюється методом шифрування 3 використанням криптографічних засобів інформації ІР-шифраторів та персональних ключів, які видаються персоналу АITC.

30 березня 2021 року Верховною Радою України було прийнято Закон України № 1357 IX "Про внесення змін деяких законодавчих актів України щодо удосконалення окремих питань виконання військового обліку" [14] в якому було винесено зміни до Закону України "Про Єдиний державний реєстр військовозобов'язаних”, а саме:

змінено назву Закону - Закон України "Про Єдиний державний реєстр призовників, військовозобов'язаних та резервістів";

перерозподілено завдання між власником ("Володільцем") ЄДРПВР - МОУ та розпорядниками Реєстру -ГШ ЗСУ, СБУ та СЗРУ;

визначено перелік Центральних органів виконавчої влади та перелік інформації, яку вони зобов'язані надавати до СДРПВР;

визначено порядок інформаційної взаємодії між визначеними ЦОВВ та ЄДРПВР, громадянином та ЄДРПВР (рис. 2) [4].

Прикінцевими та перехідними положеннями [14] були визначені завдання КМУ у шестимісячний строк 3 дня набрання чинності цим Законом (до 23.10.2021) вжити заходи, необхідні для його реалізації, прийняти нормативно-правові акти необхідні для реалізації, привести свої нормативно-правові акти у відповідність із цим законом та забезпечити приведення міністерствами та іншими центральними органами виконавчої влади їх нормативно-правових актів у відповідність із цим законом.

Науково-методичній підхід щодо удосконалення нормативно-правової бази 3 урахуванням вимог [14], було визначено у [4], але в ньому не були враховані нормативно-правові акти, що врегульовують питання інформаційної взаємодії між ЄДРПВР та іншими державними реєстрами.

Таким чином, за результатом аналізу нормативно-правового забезпечення СДРПВР встановлено, що станом на листопад 2021 року залишилися не приведеними у відповідність низка нормативно-правових актів, а саме: [12], [15]-[19].

Крім того, не розроблено нормативно-правові акти, які регламентують електронну інформаційну взаємодію ЄДРПВР 3 іншими державними реєстрами, а також відповідні нормативні акти Розпорядників СДРПВР.

Для забезпечення реалізації автоматизації та цифрової трансформації бізнес процесів військового обліку пропонується у базовий Закон України "Про Єдиний державний реєстр призовників, військовозобов'язаних та резервістів” [14] внести такі зміни:

включити до суб'єктів ЄДРПВР, визначити завдання та перелік інформації, яка в електронному автоматизованому режимі надається до ЄДРПВР такі ЦОВВ: Міністерство закордонних справ України, Національне агентство 3 питань державної служби, Національне агентство $з$ питань запобігання корупції, зокрема щодо відомостей консульського обліку громадян України за кордоном, проведення спеціальної перевірки стосовно осіб, які претендують на зайняття посад, які передбачають зайняття відповідального або особливо відповідального становища, та посад 3 підвищеним корупційним ризиком;

уточнити перелік інформації, яку в електронному автоматизованому режимі надає до ЄДРПВР Державна міграційна служби України, зокрема: оцифрований образ обличчя, унікальний номер запису у реєстрі, відомості про пенсійне забезпечення пенсіонерів МОУ тощо. 


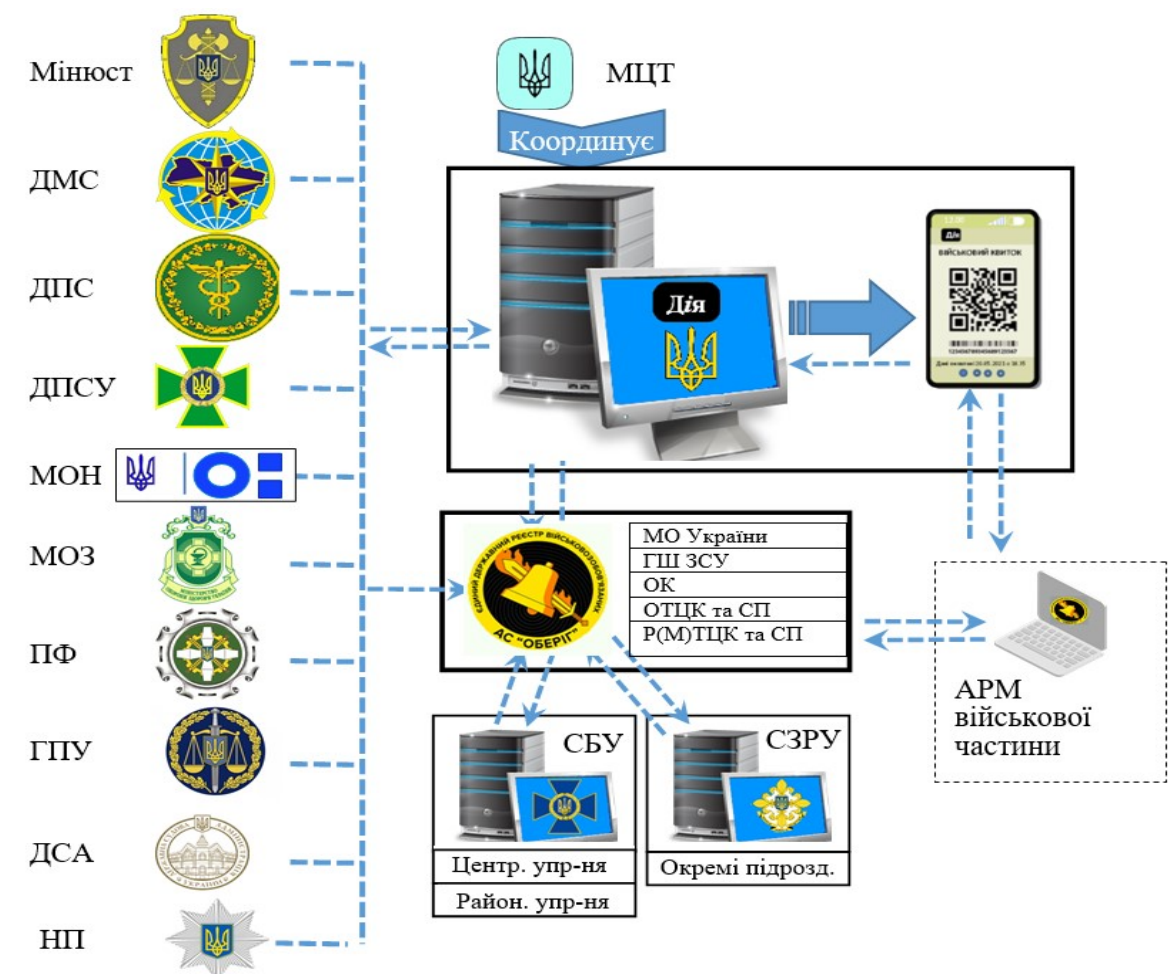

Рис. 2. Схема інформаційної взаємодії ЦОВВ із розпорядниками та користувачами ЄДРПВР в АІТС “Оберіг

До спеціальних законів України внести зміни щодо визначення інформації, яка надається в електронному автоматизованому вигляді 3 державних реєстрів до ЄДРПВР, при цьому перелік цієї інформації повинен читко узгоджуватися 3 переліком даних визначених базовим Законом України.

В акті Президента України [15] - надати повноваження МОУ визначати форми електронних військово-облікових документів.

В акті Кабінету Міністрів України [16], що визначає порядок організації та ведення військового обліку внести зміни щодо порядку використання державними органами та ТЦК та СП під час реалізації ними своїх повноважень електронних військово-облікових документів, а також надання повноважень МОУ визначати ї форми.

Акт МОУ [12], що визначає порядок ведення ЄДРПВР привести у відповідність до вимог Закону України від 30 березня 2021 року № 1357 IX [13].

В актах МОУ [17], [18], [19], які встановлюють форми військово-облікових документів призовників, військовозобов'язаних та резервістів -визначити їх електронні форми.

У спільних актах МОУ та ЦОВВ, які надають в електронному автоматизованому режимі до ЄДРПВР визначену інформацію, встановити порядок електронної інформаційної взаємодії.

Розробити необхідні розпорядчі (організаційні, та організаційно-технічні) документи щодо забезпечення функціонування ЄДРПВР 3 урахуванням уточнених завдань i функцій між Володільцем та Розпорядниками ЄДРПВР.

\section{Висновки й перспективи подальших досліджень}

Реалізація зазначених рекомендацій надає можливість створити правові засади щодо підвищення ефективності функціонування ЄДРПВР, а саме:

інтегруватися з іншими державними реєстрами та покращити достовірність облікової інформації;

автоматизувати роботу ТЦК та СП та відмовитися від “зайвих” паперових документів;

зменшити, а в деяких процесах виключити вплив людського фактору та відповідні корупційні ризики;

надати доступ громадянам до своїх облікових даних, що містяться в СДРПВР через інформаційний портал “Дія” в он-лайн режимі;

створити електронний ТЦК та СП (далі - ЕТЦК);

запровадити електронні військово-облікові документи.

Перспективними напрямами подальших досліджень можуть бути питання, які пов'язані з:

обгрунтуванням вибору архітектурносерверних рішень для реалізації інтеграційних процесів;

удосконалення спеціального програмного забезпечення;

побудови (удосконалення) комплексної системи захисту інформації;

розроблення методики оцінювання ефективності функціонування СДРПВР в тому числі органів його адміністрування та ведення;

удосконалення методики підготовки та оцінювання персоналу, а також інші напрями. 


\section{Лimepamypa}

1. Марченко В., Поняття та правове забезпечення цифрової трансформації в Україні, “Юридичний науковий електронний журнал”, 6 (2019), с. 290. 2. Правдивець О.М., Нормативно-правове забезпечення створення та функціонування інформаційної автоматизованої системи військового обліку громадян України, “Збірник наукових праць Центру воєнностратегічних досліджень Національного університету оборони України" 3(55), 2015, с.130-132. 3. Рішення Ради національної безпеки та оборони України від 20 травня 2016 року "Про Стратегічний оборонний бюлетень України", уведеного в дію Указом Президента України від 6 червня 2016 року № 240/2016. 4. Pravdyvets O. Recommendations for improvement of regulatory and legal support of automation and digital transformation of business processes of the military accounting of conscript. "Civitas et lex". 2021/2 (30) Poland. 5. Антонов В. О. Конституційно-правові засади національної безпеки України : монографія. Київ : Талком, 2017. 576 с. 6. Розпорядження Кабінету Міністрів України від 17.02.2021 № 365-р “Деякі питання цифрової трансформації розпорядження”. 7. Правдивець О. М., Козлов В. В. Основні аспекти функціонування Єдиного державного реєстру призовників i військовозобов'язаних. // Форми та способи застосування військ (сил) за досвідом проведення антитерористичної операції на території Донецької та Луганської областей: зб. матер. наук.практ. конф. (Київ, 25 жовт. 2018 р.). Київ: ЦНДІ ЗС України, 2018. С. 17-21. 8. Правдивець О. М., Козлов В. В. Призначення та порядок ведення Єдиного державного реєстру військовозобов'язаних // Актуальні проблеми планування розвитку ЗС України: зб. матер. наук.-практ. семін. (Київ, 30 лист. 2018 р.). Київ: ЦНДІ 3С України, 2018. С. 15-21. 9. Правдивець О. М., Козлов В. В. Проблеми впровадження Єдиного державного реєстру призовників i військовозобов'язаних // Актуальні проблеми планування розвитку ЗС України: зб. матер. наук.-практ. семін. (Київ, 16 травн. 2019 р.). Київ: ЦНДІ ЗС України, 2019. С. 155-160. 10. Козлов В.В., Правдивець О.М., Максимов С.О. "Перспективи автоматизації військового обліку призовників, військовозобов'язаних і резервістів" // Збірник наукових праць ЦНДІ ЗС України, № 2 (97) - К.: 2021. С. 151-158. 11. Закони України від 16.03.2017 № 1951-VIII "Про Єдиний державний реєстр військовозобов'язаних". 12. Наказ Міністерства оборони України від 08.08.2017 № 418 “Про затвердження порядку ведення Єдиного державного реєстру військовозобов'язаних". 13. Наказ Міністерства оборони України від 15.04.2019 № 180 "Про прийняття на постачання та введення в експлуатацію Збройних Сил України автоматизованої системи Єдиного державного реєстру військовозобов'язаних, шифр “Оберіг”. 14. Закон України від 30.03.2021 № 1357-IX “Про внесення змін до деяких законодавчих актів України щодо удосконалення окремих питань виконання військового обов'язку та ведення військового обліку; закон України". 15. Указ Президента України від 30.12.2016 № 582/2016 “Про Положення про військовий квиток осіб рядового, сержантського і старшинського складу та Положення про військовий квиток офіцерів запасу". 16. Постанова Кабінету Міністрів України від 07.12.2016 № 921 “Про затвердження Порядку організації та проведення військового обліку призовників і військовозобов'язаних". 17. Наказ Міністра оборони України від 10.12.2010 № 650 "Про затвердження деяких нормативно-правових актів, що регламентують питання організації та порядку ведення військового обліку офіцерів запасу, атестування осіб до присвоення первинних та чергових військових звань офіцерського складу запасу, а таож зразка військового квитка офіцерів". 18. Наказ Міністерства оборони України від 10.04.2017 № 206 "Про військовий квиток осіб рядового, сержантського і старшинського складу”. 19. Наказ Міністерства оборони України від 21.11.2017 № 610 “Про тимчасове посвідчення військовозобов'язаного”.

\title{
ЦЫФРОВИЗАЦИЯ ОБЩЕСТВА И ОРГАНИЗАЦИОННО-ПРАВОВЫЕ МЕХАНИЗМИ ФУНКЦИОНИРОВАНИЯ ЕДИНОГО ГОСУДАРСТВЕННОГО РЕЕСТРА ПРИЗЫВНИКОВ, ВОЕННООБЯЗАННЫХ И РЕЗЕРВИСТОВ
}

\author{
Александр Николаевич Правдивец (кандидат военных наук)
}

\section{Национальный университет обороны Украины имени Ивана Черняховского, Киев}

В статье охарактеризовань организационно-правовые механизмы функционирования Единого государственного реестра призывников, военнообязанных и резервистов. Проведен анализ нормативноправового обеспечения государственных механизмов функиионирования Единого государственного реестра призывников, военнообязанных и резервистов как направление государственной политики Украины. Обоснованы рекомендации по усоверченствованию нормативно-правовых актов, которые определяют организационно-правовые механизмы функционирования Единого государственного реестра призывников, военнообязанных и резервистов.

Применение этих рекомендаций в практической деятельности Центральных органов исполнительной власти, в частности, в ходе формирования политики цифровой трансформации в Министерстве оборонь Украинь относительно интеграции Единого государственного реестра призывников, военнообязанных и резервистов введет необходимые правовые механизмы для организации и обеспечения информационного взаимодействия между государственными реестрами в интересах ведения военного учета граждан Украины для комплектования войск (сил) личным составом.

Кроме того, практическая реализация рекомендаций создаст правовые основы для реализаџии Министерством обороны Украины проектов, предусмотренных Планом действий Правительства по внедрению электронных военно-учетных документов и созданию электронного Территориального центра комплектования и сочиальной поддержки.

Ключевые слова: Единый государственный реестр призывников, военнообязанных и резервистов. 


\title{
DIGITALIZATION OF SOCIETY AND ORGANIZATIONAL AND LEGAL MECHANISMS OF FUNCTIONING OF THE UNIFIED STATE RESERVES REGISTER
}

\author{
Oleksandr Pravdivets (Candidate of military sciences)
}

\author{
National Defence University of Ukraine named after Ivan Cherniakhovskyi, Kyiv, Ukraine
}

The article describes the organizational and legal mechanisms of the Unified State Register. An analysis of the regulatory and legal support of state mechanisms for the functioning of the Unified State Register, as a direction of state policy of Ukraine. Recommendations for improving the regulations that determine the organizational and legal mechanisms of the Unified State Register are substantiated.

The application of these recommendations in the practice of the Central Executive Bodies, in particular during the formation of the digital transformation policy in the Ministry of Defense of Ukraine on the integration of the Unified State Register will introduce the necessary legal mechanisms for organizing and ensuring information interaction between state registers. military registration of citizens of Ukraine for manning troops (forces).

In addition, the practical implementation of the recommendations will create a legal basis for the implementation by the Ministry of Defense of Ukraine of projects envisaged by the Government Action Plan for the introduction of electronic military records and the creation of an electronic Territorial Center for Recruitment and Social Support.

Key words: Unified state register of conscripts, conscripts and reservists, integration, digitalization.

\section{References}

1. Marchenko V., Poniattia ta pravove zabezpechennia tsyfrovoi transformatsii v Ukraini, "Iurydychnyi naukovyi elektronnyi zhurnal", 6 (2019), s. 290. 2. Pravdyvets O.M., Normatyvno-pravove zabezpechennia stvorennia ta funktsionuvannia informatsiinoi avtomatyzovanoi systemy viiskovoho obliku hromadian Ukrainy, "Zbirnyk naukovykh prats Tsentru voienno-stratehichnykh doslidzhen Natsionalnoho universytetu oborony Ukrainy" 3(55), 2015, s.130-132. 3. Rishennia Rady natsionalnoi bezpeky ta oborony Ukrainy vid 20 travnia 2016 roku "Pro Stratehichnyi oboronnyi biuleten Ukrainy", uvedenoho v diiu Ukazom Prezydenta Ukrainy vid 6 chervnia 2016 roku № 240/2016. 4. Pravdyvets O. Recommendations for improvement of regulatory and legal support of automation and digital transformation of business processes of the military accounting of conscript. "Civitas et lex". 2021/2 (30). Poland. 5. Antonov V. O. Konstytutsiino-pravovi zasady natsionalnoi bezpeky Ukrainy : monohrafiia. Kyiv : Talkom, 2017. 576 s. 6. Rozporiadzhennia Kabinetu Ministriv Ukrainy vid 17.02.2021 № 365-r "Deiaki pytannia tsyfrovoi transformatsii rozporiadzhennia". 7. Pravdyvets O. M., Kozlov V. V. Osnovni aspekty funktsionuvannia Yedynoho derzhavnoho reiestru pryzovnykiv i viiskovozoboviazanykh. // Formy ta sposoby zastosuvannia viisk (syl) za dosvidom provedennia antyterorystychnoi operatsii na terytorii Donetskoi ta Luhanskoi oblastei: zb. mater. nauk.-prakt. konf. (Kyiv, 25 zhovt. 2018 r.). Kyiv: TsNDI ZS Ukrainy, 2018. S. 17-21. 8. Pravdyvets O. M., Kozlov V. V. Pryznachennia ta poriadok vedennia Yedynoho derzhavnoho reiestru viiskovozoboviazanykh // Aktualni problemy planuvannia rozvytku ZS Ukrainy: zb. mater. nauk.-prakt. semin. (Kyiv, 30 lyst. 2018 r.). Kyiv: TsNDI ZS Ukrainy, 2018. S. 15-21. 9. Pravdyvets O. M., Kozlov V. V. Problemy vprovadzhennia Yedynoho derzhavnoho reiestru pryzovnykiv i viiskovozoboviazanykh // Aktualni problemy planuvannia rozvytku ZS Ukrainy: zb. mater. nauk.-prakt. semin. (Kyiv, 16 travn. 2019 r.). Kyiv: TsNDI ZS Ukrainy,
2019. S. 155-160. 10. Kozlov V.V., Pravdyvets O.M., Maksymov S.O. "Perspektyvy avtomatyzatsii viiskovoho obliku pryzovnykiv, viiskovozoboviazanykh i rezervistiv" // Zbirnyk naukovykh prats TsNDI ZS Ukrainy, № 2 (97) K.: 2021. S. 151-158. 11. Zakony Ukrainy vid 16.03.2017 № 1951-VIII "Pro Yedynyi derzhavnyi reiestr viiskovozoboviazanykh". 12. Nakaz Ministerstva oborony Ukrainy vid 08.08.2017 № 418 "Pro zatverdzhennia poriadku vedennia Yedynoho derzhavnoho reiestru viiskovozoboviazanykh". 13. Nakaz Ministerstva oborony Ukrainy vid 15.04.2019 № 180 "Pro pryiniattia na postachannia ta vvedennia v ekspluatatsiiu Zbroinykh Syl Ukrainy avtomatyzovanoi systemy Yedynoho derzhavnoho reiestru viiskovozoboviazanykh, shyfr "Oberih". 14. Zakon Ukrainy vid 30.03.2021 № 1357-IX "Pro vnesennia zmin do deiakykh zakonodavchykh aktiv Ukrainy shchodo udoskonalennia okremykh pytan vykonannia viiskovoho oboviazku ta vedennia viiskovoho obliku: zakon Ukrainy". 15. Ukaz Prezydenta Ukrainy vid 30.12.2016 № 582/2016 "Pro Polozhennia pro viiskovyi kvytok osib riadovoho, serzhantskoho i starshynskoho skladu ta Polozhennia pro viiskovyi kvytok ofitseriv zapasu". 16. Postanova Kabinetu Ministriv Ukrainy vid 07.12.2016 № 921 "Pro zatverdzhennia Poriadku orhanizatsii ta provedennia viiskovoho obliku pryzovnykiv i viiskovozoboviazanykh". 17. Nakaz Ministra oborony Ukrainy vid 10.12.2010 № 650 "Pro zatverdzhennia deiakykh normatyvno-pravovykh aktiv, shcho rehlamentuiut pytannia orhanizatsii ta poriadku vedennia viiskovoho obliku ofitseriv zapasu, atestuvannia osib do prysvoennia pervynnykh ta cherhovykh viiskovykh zvan ofitserskoho skladu zapasu, a taozh zrazka viiskovoho kvytka ofitseriv". 18. Nakaz Ministerstva oborony Ukrainy vid 10.04.2017 № 206 "Pro viiskovyi kvytok osib riadovoho, serzhantskoho i starshynskoho skladu". 19. Nakaz Ministerstva oborony Ukrainy vid 21.11.2017 № 610 "Pro tymchasove posvidchennia viiskovozoboviazanoho". 